\title{
Identification of Antifungal Metabolites of Lactic Acid Bacteria
}

\author{
Cissé Mohamed*, N'guessan Elise Amoin and Assoi Sylvie \\ Université Peleforo Gon Coulibaly de Korhogo (Cote d'Ivoire) \\ *Corresponding author
}

\begin{tabular}{|l}
\hline Ke y w or d s \\
Antifungal \\
metabolites, Lactic \\
acid bacteria, pH
\end{tabular}

\section{A B S T R A C T}

Antifungal activity of lactic acid bacteria in food preservation is one of the technological properties sought. The antifungal effect of lactic acid bacteria has been studied. Four strains namely Lactobacillus plantarum G100, Lactobacillus brevis L62, Lactobacillus rhamnosus THT and Pediococcus pentosaceus Hela showed inhibitory activity against Tricoderma F14, Penicillium canescens 10-10 C, Aspergillus niger and Rhyzopus stoloniferous. Antifungal activity of L. rhamnosus THT strain depended mostly on the presence of these organic acids. L. brevis L62 and P. pentosaceus Hela strains depended on the production of hydrogen peroxide, especially in acidic media. Lactobacillus plantarum G100 still remains insensitive to the action of hydrogen peroxide, but its antagonism effect was reduced after subjecting its supernatant to a protease treatment at this same $\mathrm{pH}$ of 7. L. plantarum G100 activity could be ascribe to the presence of peptide compounds as well as that of organic acids. The inhibitory effect was even higher when the $\mathrm{pH}$ of the medium was between 3 and 4.5. Loss of this activity was remarked when $\mathrm{pH}$ was above 6. Lastly, whatever the nature of the metabolites secreted into the culture medium, their activities remained effective when the $\mathrm{pH}$ was acidic and quite similar to the $\mathrm{pH}$ observed at the end of the culture period.

\section{Introduction}

Molds are microorganisms responsible for significant deterioration of foodstuffs. Their presence in food causes great economic losses around the world. It is estimated that about 5 to $10 \%$ of food production is corrupted by these organisms (Pitt and Hocking, 1999). According to Corssetti et al., (1998) the annual economic loss in occidental Europe ascribed to molds is around $£ 242$ million. It should also be noted that mold growth is accountable to most common deterioration of bread. Moreover, beside mold, the concomitant production of allergenic spores and the possible presence of toxic and carcinogenic mycotoxins in food are also of particular interest (Ström, 2005). The multiple variations observed in the intrinsic ( $\mathrm{pH}$ and water activity) and extrinsic (storage temperature and the presence of other microorganisms) factors of food make it an excellent medium for various microbial growth (Montville and Matthews, 2001). Food taste and appearance can also be strongly altered by the presence of fungi. Furthermore, their presence in foods may present serious potential health risks. 
Ways to reduce food deterioration may involve the use of physical methods (heat treatments, cold storage, modification of the storage atmosphere, drying, lyophilization) or addition of preserving additives, which can be of chemical nature or bio-preservatives made of microorganisms or their metabolites.

Lately, it has been established that an increasing number of microbial species were becoming resistant to antibiotics including Fungus. Schnürer et al., (2005) indicated that in addition to antibiotic resistance they also exhibit resistance to food additive such as sorbic and benzoic acids. Indeed, Davidson (2001) reported growth of Penicillium species in food stuffs despite the presence of potassium sorbate and moreover, the number of mold species capable of degrading sorbate is on the rise. Resistance to benzoate has been reported for Penicillium roqueforti as well (Nielsen and De Boer, 2000).

One way to cope with the resistance of food microorganisms to antibiotic and food additives is the use of lactic acid bacteria. Theses bacteria are potentially interesting candidates for food preservation since during their use as bactericidal agent, it has been discovered that they could also be a great asset in the fight against fungi. Their preservation attributes are mainly due to food $\mathrm{pH}$ reduction, organic acid production (lactic acid and acetic acid), competition with contaminating microflora for food nutrients and to the presence of other compounds such as hydrogen peroxide, peptide compounds, etc. (Lowe and Arendt, 2004).

Nowadays, with the growing awareness of customers for natural food ingredients and additives, the use of lactic acid bacteria, commonly found in human gut and also used in fermented dairy products (yogurts, cheese, etc), would be a great way to produce more natural and healthy food. Drouault, and
Corthier, (2001) highlighted the usefulness of these bacteria through their protective and stimulating effect on the human body.

This present study was conducted to identify bacterial strains with antifungal properties against Tricoderma F14, P. canescens 10-10 C, Aspergillus niger and Rhizopus stoloniferous and to determine the type of the inhibition involved in the process.

\section{Materials and Methods}

Nine strains of lactic acid bacteria (Lactobacillus plantarum G100, Lactobacillus plantarum L115, Lactobacillus brevis L62, Lactococcus lactis lactis N'Bannik Senegal, Lactobacillus curvatus RM7, Pediococcus pentosaceus Hela, Lactobacillus rhamnosus THT, Lactococcus sake THT, Staphylococcus xylosus M86 THT) and four strains of molds (Tricoderma F14, P. canescens 10-10 C, Aspergillus niger and Rhizopus stoloniferous) were obtained from the laboratory of Walloon Center for Industrial Biology (CWBI) of the Liège University (Belgium).

\section{Preparation of the bacterial solution}

Seven day colonies of bacterial strains were inoculated into $250 \mathrm{ml}$ flasks containing 100 $\mathrm{ml}$ of MRS liquid medium. The flask was incubated at $30^{\circ} \mathrm{C}$ for $48 \mathrm{~h}$ under continuous shaking (130 rpm) and the liquid medium was then centrifuged ((Beckman, California, USA) at 10,000 at $4^{\circ} \mathrm{C}$ for 20 minutes. After centrifugation, the supernatant was recovered and filtered through a $0.45 \mu \mathrm{m}$ filter (VWR cellulose acetate Leuven, Belgium).

\section{Antifungal effect of lactic acid bacteria}

Lactic acid bacteria effects on the growth of various molds were investigated using the agar diffusion method (Roy et al., 1996). A $100 \mu \mathrm{l}$ of the fungal suspension containing $10^{7}$ spores 
/ $\mathrm{ml}$ were homogeneously spread out on the surface of a petri dish containing carbonated MRS medium within which 4 equidistant wells of $6 \mathrm{~mm}$ diameter were made. Next, 10 $\mathrm{ml}$ of the bacterial supernatant were carefully distributed into each well and the petri dish was incubated at $30^{\circ} \mathrm{C}$ for $72 \mathrm{~h}$. Each of the 4 wells was inoculated with a specific bacterial strain in order to study its effect on the growth of the mold strain spread out on the carbonated MRS medium. The appearance of a clear zone around a well would indicate the growth inhibition of the fungal strain. Measurement of the inhibition diameters was done after 72 hours of incubation time. For each experiment conducted, four replicates were prepared.

Identification of the substances responsible for the inhibition

The action of substances that may have antifungal activity has been studied step by step in order to determine the specific influence of each of them. This identification will only concern bacteria exhibiting a clear inhibition against molds.

\section{Effect of MRS Medium on Mold Growth}

To determine if the $\mathrm{pH}$ of the MRS liquid medium, used for lactic acid bacterial growth, displayed an antifungal activity, the agar diffusion test was conducted. A $10 \mu \mathrm{l}$ of MRS medium with $\mathrm{pH}$ ranging from 7 (initial $\mathrm{pH}$ ) to 2 was put in the wells of the agar and the effect of the acidity of the MRS medium on the fungal growth was evaluated. The $\mathrm{pH}$ of the medium was adjusted with $6 \mathrm{~N}$ or $0.1 \mathrm{~N}$ HCL solution.

\section{Effect of sodium acetate on the antifungal activity of the MRS medium}

To assess the influence of the Sodium acetate, found in the MRS medium, on growth of fungal strains, the antifungal test of bacterial supernatants was performed.

For this study, two types of MRS agar were used. The MRS agar containing the sodium acetate was labelled MRSac while the one without it was called MRS. After spreading $100 \mu \mathrm{L}$ of fungal suspension on the MRSac and MRS agar plates, $10 \mu \mathrm{L}$ of bacterial supernatant was put in the wells. The Plates were then incubated at $30^{\circ} \mathrm{C}$. The inhibition zones observed on the plates were then measured and compared to evaluate a possible action of the sodium acetate on fungal growth.

\section{The effect of organic acid production on fungal strains growth}

The influence of the acidity of the supernatant was tested on the growth of fungal strains. Before filtration, the $\mathrm{pH}$ of the supernatant recovered after centrifugation of the MRS liquid medium was adjusted to $\mathrm{pH} 7$ by addition of $6 \mathrm{~N}$ or $0.1 \mathrm{~N} \mathrm{NaOH}$ solution. The obtained solution was tested on fungal strains.

The disappearance of inhibition zone would show a marked effect of the action of the organic acids. A decrease in the diameter of the inhibition zone would indicate an effect of the $\mathrm{pH}$ of the supernatant, but also that of another antifungal substance.

\section{Study of the effect of hydrogen peroxide}

\section{Catalase test}

The catalase test was done to determine if the lactic acid bacteria were able to degrade hydrogen peroxide. For this analysis, a bacterial colony was taken on the MRS agar and was deposited on a slide containing a drop of hydrogen peroxide. The presence of catalase would be reflected by the appearance of an effervescence which would reveal the release of oxygen. 
Elimination of the effect of hydrogen peroxide

The supernatant of the MRS liquid medium recovered after centrifugation was divided into two parts. One part was filtered on a $0.45 \mu \mathrm{m}$ filter while the other one was filtered in a sterile condition after adjusting its $\mathrm{pH}$ to 7 . This $\mathrm{pH} 7$ supernatant was used to determine if the inhibitory activity was dependent on both the organic acids and the hydrogen peroxide substances.

A $0.15 \mathrm{ml}$ of catalase (Sigma, EC.1.11.1.6), prepared by using a $10 \mathrm{mg} / \mathrm{ml}$ phosphate buffer $\left(\mathrm{K}_{2} \mathrm{HPO}_{4} / \mathrm{KH}_{2} \mathrm{PO}_{4}, \mathrm{pH}\right)$ solution, was added to $0.135 \mathrm{ml}$ of the bacterial supernatants so as to obtain a final concentration of $1 \mathrm{mg} /$ $\mathrm{ml}$. The mixture was placed at $30^{\circ} \mathrm{C}$ for 1 hour for reactions to occur. A control was prepared with $0.135 \mathrm{ml}$ of the tested supernatant supplemented with $0.15 \mathrm{ml}$ of phosphate buffer without catalase.

The inhibition test was therefore carried out using the same conditions as above. As compared to the control, the loss of the inhibition zone showed an antagonistic effect due to the presence of hydrogen peroxide. Moreover, a decrease in the inhibition zone diameter showed a combined effect of hydrogen peroxide and another inhibitory substance.

\section{Effect of proteases on the inhibitory activity of bacterial supernatants}

The supernatant recovered after centrifugation was divided into two half. One part was filtered on a $0.45 \mu \mathrm{m}$ filter paper whereas the $\mathrm{pH}$ of the other part was adjusted to 7 before filtration. A $0.15 \mathrm{~mL}$ of the phosphate buffer solution containing $\alpha$-chymotrypsin protease (Sigma, EC.3.4.21.1) was added to $1.35 \mathrm{~mL}$ of bacterial supernatant. The enzyme concentration in the final solution was
1mg.mL-1. The enzymatic reaction was stopped by denaturation of the proteases at $100^{\circ} \mathrm{C}$. for 3 minutes.

The control consisted of $1.35 \mathrm{ml}$ of bacterial supernatant supplemented with $0.15 \mathrm{ml}$ of buffer prepared without $\alpha$-chymotrypsin protease. This mixture was subjected to the same heat treatment as above.

The inhibition test was therefore performed. When compared to the control, the treated supernatant displayed a loss of the inhibition zone thus demonstrating sensitivity to a protease. A decrease in the inhibition zone diameter exposed a combined effect of the protease with another inhibitory substance.

\section{Results and Discussion}

\section{Inhibition test in MRS agar medium}

After 48 hours of incubation at $30^{\circ} \mathrm{C}$., the inhibition zone measured around the well was represented in Figure 1 and 2. The results showed that, four strains of lactic acid bacteria, namely $L b$. plantarum G100, $L b$. brevis L62, Lb. rhamnosus THT, and $P$. pentosaceus Hela, clearly displayed an inhibition zone diameter greater than $10 \mathrm{~mm}$ thus revealing a higher inhibitory activity on mold growth. The other lactic acid bacteria, viz. L. plantarum L115, L. lactis lactis N'Bannik Senegal, L. curvatus RM7, L. sake $T H T$, and S. xylosus M86 THT, showed little or no inhibitory $(0-3 \mathrm{~cm})$ inhibitory activity against fungal

\section{Identification of antifungal metabolites}

Action of the MRS culture medium on molds

Antifungal activity of MRS liquid medium at different $\mathrm{pH}$ (2-7) was evaluated. Results are shown in Figure 3. No inhibition zone was 
observed around the wells at $\mathrm{pH} 7$ (initial $\mathrm{pH}$ ). On the other hand, when the $\mathrm{pH}$ was lowered up to $\mathrm{pH} 3$, the MRS liquid medium was beginning to display an inhibitory activity on Tricoderma F14, P. canescens $10-10 \mathrm{C}$ and $\mathrm{R}$ stoloniferous strains. This inhibitory activity increased when $\mathrm{pH}$ was further lowered to $\mathrm{pH}$ 2 with a maximum inhibitory diameter of 2.5 $\mathrm{mm}$ on $P$. canescens 10-10 C against a minimum of $0.5 \mathrm{~mm}$ inhibitory diameter on stoloniferous $\mathrm{R}$. The growth of $\mathrm{A}$. niger strain was not affected by the change of $\mathrm{pH}$ (from 7 to 2)

\section{Influence of sodium acetate on antifungal compounds}

The antifungal activity of the acetate found in the MRS agar medium is shown in Table 1. It could be noted that there was no significant difference between the antifungal activities of the supernatants on MRSac and MRS medium. The presence of acetate in the medium had no effect on the bacterial supernatants activity.

\section{Study of the effect of organic acids}

This study was concerned only with bacterial strains exhibiting antifungal activity, namely Lb. Plantarum G100, Lb. Rhamnosus THT, Lb. brevis L62 and P. pentosaceus Hela. After fixing the $\mathrm{pH}$ to 7 , the different bacterial strains exhibited various behaviors based on the selected molds. The different bacterial supernatants obtained at the $\mathrm{pH}$ when the bacterial culture was achieved showed a better inhibitory activity as compared to the supernatant obtained at $\mathrm{pH}$ 7. These $\mathrm{pHs}$ obtained at the end of the culture varied between 3.6 and 4.7 hence illustrating the amount of acid produced (lactic acid, acetic acid, etc.)

In the presence of acid substances, Lactobacillus rhamnosus had almost lost its antifungal activity on various molds. Indeed, the average inhibition zone observed for this bacterium dropped from $12 \mathrm{~cm}$ to $2 \mathrm{~cm}$.

For the remaining bacteria (Lactobacillus brevis L62, Pediococcus pentosaceus hela, and Lactobacillus plantarum G100), a slight decrease in the diameter of the inhibition zone (from 16 to $10 \mathrm{~mm}$ ) was also noticed. Therefore, it could be stated that the antifungal activity of these bacterial species were also affected by the presence of organic acids.

\section{Study of the effect of hydrogen peroxide}

No effervescence effect was observed after putting hydrogen peroxide on the colonies of each bacterial strain. This result denoted that all the bacteria studied were catalase negative (Table 2).

The influence of hydrogen peroxide on the antifungal activity of bacterial supernatants obtained at $\mathrm{pH} 7$ and also at the end-of-culture $\mathrm{pH}$ is presented in Table 3. Compared to the control, there was a considerable decrease in the inhibition zone diameter for the Lactobacillus brevis L62 and Pediococcus pentosaceus hela strains. These results revealed that the antifungal activity of these bacterial species was affected by the production of hydrogen peroxide. However, not much change in the inhibition zones diameter was noticed with the strain Lactobacillus plantarum G100 when compared to the control. The inhibitory activity of this strain depends neither on hydrogen peroxide nor the synergistic effect between organic acids and hydrogen peroxide. The antifungal activity of this bacterium might be provided by another antifungal substance.

With bacterial supernatants obtained at $\mathrm{pH}$ of the end of culture (Table 4), the strain Lactobacillus rhamnosus THT regained its antifungal activity thanks to the presence of 
organic acids. When compared to the control, the inhibition zones diameters of this bacterial strain remain substantially identical. This result confirmed that the antifungal effect of Lactobacillus rhamnosus THT was related to the presence of organic acids.

Strains of Lactobacillus brevis L62 and Pediococcus pentosaceus Hela exhibited a smaller inhibition zone diameter as compared to the controls without catalase. The antifungal activity of these two bacterial strains was dependent on the presence of hydrogen peroxide. These results also demonstrated the influence of hydrogen peroxide on molds growth.

However, when comparing the activity of these bacteria at $\mathrm{pH} 7$ and pHec (Table 3 and 4), it was noted that Lactobacillus brevis L62 and Pediococcus pentosaceus Hela exhibited a greater inhibitory action on molds when the $\mathrm{pH}$ was that of the end of culture. Here, there could be a synergistic inhibitory effect between hydrogen peroxide and organic acids.

The antifungal effect of Lactobacillus plantarum G100 was not significantly affected by the antagonism between hydrogen peroxide and organic acids. On the other hand, there was a slight decrease in antifungal activity when the $\mathrm{pH}$ was set at 7 .

\section{Effect of a protease on the inhibitory activity of bacterial supernatants}

Lactic acid bacteria are known to produce a large number of antifungal substances which were of peptide nature. The action of $\alpha$ chymotrypsin on bacterial supernatants at the $\mathrm{pH}$ of the end of culture and $\mathrm{pH} 7$ was studied. Results are shown in Tables 5 and 6 respectively.

Bacterial supernatants lacking protease exhibited greater inhibition activity than the protease-treated supernatants. For Lactobacillus plantarum G100 the proteinaceous nature of its antifungal substances was thus verified.

The inhibition zones of Lactobacillus plantarum G100 decreased markedly after addition of the protease in the supernatants obtained at the pHec. This decrease pointed out a reduced antifungal activity in the presence of protease. The inhibition zones of the other bacterial strains showed a slight modification but were not dependent on proteinaceous substances.

When the bacterial supernatants containing $\alpha$ chymotrypsin are neutralized to $\mathrm{pH} 7$, more decrease in the Lactobacillus plantarum G100 antifungal activity was observed as compared to the same supernatant obtained at the pHec (Table 7). For the other strains, the reduction of the net inhibition zone was caused by the presence of organic acids.

It was noticed that protease has less effect on Lactobacillus brevis 162, Rhamnosus tht and Pediococcus Hela.

These results showed that the substance responsible for the antifungal activity of Lactobacillus plantarum G100 could be of proteinaceous nature. The activity of these antifungal peptides was enhanced by the presence of organic acids or other $\mathrm{pH}$ dependent compounds. After treatment with $\alpha$ chymotrypsin, the inhibition zone diameter the Lb plantarum G100 gray strain dropped meaning that this strain was sensitive to the presence of peptide compounds.

Fungal strains inhibition did not depend on MRS liquid medium but rather on the metabolites secreted during the culture by $L b$. plantarum G100, Lb. brevis L62, Lb. rhamnosus THT, and $P$. pentosaceus Hela into the medium. In contrary to the founding 
reported by Stiles et al., (2003), the sodium acetate found in the MRS gelose had no effect on the antifungal compounds produced by the different bacteria studied. The secreted metabolites consisted of organic acids, hydrogen peroxide and protease. The different bacterial supernatants obtained at the $\mathrm{pH}$ of the end of culture showed a better inhibitory activity compared to the supernatant of $\mathrm{pH} 7$. The values of the $\mathrm{pH}$ of end of culture varied between 3.6 and 4.7 were in fact an illustration of the amount of acid (lactic acid, acetic acid) present in the medium. These organic acids can only penetrate the cellulosic membrane when they are in their undissociated form. This usually happens when their pka value is above that of their $\mathrm{pH}$ value. Since the pka value of the acid produced during the culture was below 5, adjusting the $\mathrm{pH}$ above this value would stop or reduce the effect of these acids therefore the antifungal effect of the bacterial supernatants. Organic acids secreted into the medium appear to be the most important antifungal metabolites since their absence decreases or suppresses the inhibitory effect of the bacterial supernatants. The chief activity of these organic acids has been specified by Ström (2005).

Table.1 Comparative study of the antifungal activity between the culture medium containing sodium acetate (MRS) and the medium without (MRS-ac)

\begin{tabular}{|c|c|c|c|c|c|c|c|c|}
\hline \multicolumn{9}{|c|}{ Diamètre de la zone d'inhibition (mm) } \\
\hline & $\begin{array}{c}\text { Lb. plantarum. } \\
\text { G100 }\end{array}$ & \multicolumn{2}{c|}{$\begin{array}{c}\text { Lb. rhamnosus } \\
\text { THT }\end{array}$} & \multicolumn{2}{c|}{ Lb. brevis L62 } & \multicolumn{2}{c|}{$\begin{array}{c}\text { P.pentosaceus } \\
\text { Hela }\end{array}$} \\
\hline & MRS & MRS-ac & MRS & MRS-ac & MRS & MRS-ac & MRS & MRS-ac \\
\hline R. stolonifer & $15^{\mathrm{a}} \pm 5$ & $12^{\mathrm{a}} \pm 3$ & $11^{\mathrm{a}} \pm 3$ & $13^{\mathrm{a}} \pm 3$ & $15^{\mathrm{a}} \pm 1$ & $13^{\mathrm{a}} \pm 3$ & $13^{\mathrm{a}} \pm 5$ & $15^{\mathrm{a}} \pm 4$ \\
\hline $\boldsymbol{A}$. niger & $20^{\mathrm{a}} \pm 2$ & $18^{\mathrm{a}} \pm 2$ & $16^{\mathrm{a}} \pm 7$ & $14^{\mathrm{a}} \pm 5$ & $16^{\mathrm{a}} \pm 7$ & $18^{\mathrm{a}} \pm 5$ & $15^{\mathrm{a}} \pm 2$ & $13^{\mathrm{a}} \pm 6$ \\
\hline Trichod. F14 & $14^{\mathrm{a}} \pm 8$ & $11^{\mathrm{a}} \pm 4$ & $12^{\mathrm{a}} \pm 2$ & $10^{\mathrm{a}} \pm 8$ & $12^{\mathrm{a}} \pm 2$ & $9^{\mathrm{a}} \pm 2$ & $14^{\mathrm{a}} \pm 1$ & $15^{\mathrm{a}} \pm 5$ \\
\hline $\boldsymbol{P . 1 0 - 1 0 C}$ & $10^{\mathrm{a}} \pm 5$ & $13^{\mathrm{a}} \pm 1$ & $10^{\mathrm{a}} \pm 5$ & $8^{\mathrm{a}} \pm 3$ & $10^{\mathrm{a}} \pm 4$ & $11^{\mathrm{a}} \pm 3$ & $12^{\mathrm{a}} \pm 0$ & $12^{\mathrm{a}} \pm 3$ \\
\hline
\end{tabular}

Table. 2 catalase test of lactic acid bacteria

\begin{tabular}{|l|l|l|l|}
\hline & $\begin{array}{l}\text { Lb. plantarum. } \\
\text { G100 }\end{array}$ & Lb. brevis L62 & $\begin{array}{l}\text { Pediococcus } \\
\text { pentosaceus hela }\end{array}$ \\
\hline Catalase & - & - & - \\
\hline
\end{tabular}

Table.3 Diameter of inhibition zone of lactic bacteria supernatants at $\mathrm{pH} 7$ with or without catalase

\begin{tabular}{|l|c|c|c|c|c|c|}
\hline \multicolumn{7}{|c|}{ Diameter of inhibition (mm) } \\
\hline & \multicolumn{2}{|c|}{$\begin{array}{c}\text { Lb. plantarum. } \\
\text { G100 }\end{array}$} & \multicolumn{2}{c|}{ Lb. brevis L62 } & \multicolumn{2}{c|}{$\begin{array}{c}\text { Pediococcus } \\
\text { pentosaceus hela }\end{array}$} \\
\hline & $\begin{array}{c}\text { no } \\
\text { catalase }\end{array}$ & $\begin{array}{c}\text { with } \\
\text { catalase }\end{array}$ & $\begin{array}{c}\text { no } \\
\text { catalase }\end{array}$ & $\begin{array}{c}\text { with } \\
\text { catalase }\end{array}$ & $\begin{array}{c}\text { no } \\
\text { catalase }\end{array}$ & $\begin{array}{c}\text { with } \\
\text { catalase }\end{array}$ \\
\hline R. stolonifer & $10^{\mathrm{a}} \pm 3$ & $7 \pm 5^{\mathrm{b}}$ & $10^{\mathrm{a}} \pm 2$ & $4^{\mathrm{b}} \pm 1$ & $9^{\mathrm{a}} \pm 2$ & $5^{\mathrm{b}} \pm 2$ \\
\hline A. niger & $10^{\mathrm{a}} \pm 2$ & $12^{\mathrm{a}} \pm 2$ & $10^{\mathrm{a}} \pm 4$ & $5^{\mathrm{b}} \pm 3$ & $12^{\mathrm{a}} \pm 1$ & $5^{\mathrm{b}} \pm 1$ \\
\hline Trichoder. & $9^{\mathrm{a}} \pm 4$ & $7^{\mathrm{a}} \pm 1$ & $8^{\mathrm{a}} \pm 3$ & $2^{\mathrm{b}} \pm 0$ & $8^{\mathrm{a}} \pm 4$ & $4^{\mathrm{b}} \pm 1$ \\
\hline $\boldsymbol{P . 1 0 - 1 0}$ & $9^{\mathrm{a}} \pm 2$ & $9^{\mathrm{a}} \pm 4$ & $6^{\mathrm{a}} \pm 1$ & $3^{\mathrm{b}} \pm 1$ & $7^{\mathrm{a}} \pm 3$ & $2^{\mathrm{b}} \pm 0$ \\
\hline
\end{tabular}


Table.4 Diameter of inhbiton zone of lactic bacteria supernatant obtained at the $\mathrm{pH}$ of the end of culture (pHec) supplemented with or without catalase

\begin{tabular}{|c|c|c|c|c|c|c|c|c|}
\hline \multicolumn{9}{|c|}{ Diameter of inhibition (mm) } \\
\hline & \multicolumn{2}{|c|}{$\begin{array}{c}\text { Lb. plantarum. } \\
\text { G100 }\end{array}$} & \multicolumn{2}{|c|}{$\begin{array}{c}\text { Lb. rhamnosus } \\
\text { THT }\end{array}$} & \multicolumn{2}{|c|}{ Lb. brevis $\mathrm{L62}$} & \multicolumn{2}{|c|}{$\begin{array}{c}\text { P. pentosaceus } \\
\text { hela }\end{array}$} \\
\hline & $\begin{array}{c}\text { Sans } \\
\text { catalase }\end{array}$ & $\begin{array}{c}\text { Avec } \\
\text { catalase }\end{array}$ & $\begin{array}{c}\text { Sans } \\
\text { catalase }\end{array}$ & $\begin{array}{c}\text { Avec } \\
\text { catalase }\end{array}$ & $\begin{array}{c}\text { Sans } \\
\text { catalase }\end{array}$ & $\begin{array}{c}\text { Avec } \\
\text { catalase }\end{array}$ & $\begin{array}{c}\text { Sans } \\
\text { catalase }\end{array}$ & $\begin{array}{c}\text { Avec } \\
\text { catalase }\end{array}$ \\
\hline R. stolonifer & $14^{\mathrm{a}} \pm 5$ & $13^{\mathrm{a}} \pm 1$ & $12^{a} \pm 5$ & $9^{a} \pm 3$ & $15^{\mathrm{a}} \pm 5$ & $6^{b} \pm 3$ & $13^{\mathrm{a}} \pm 2$ & $8^{b} \pm 4$ \\
\hline A. niger & $18^{\mathrm{a}} \pm 3$ & $13^{\mathrm{b}} \pm 5$ & $15^{\mathrm{a}} \pm 2$ & $12^{\mathrm{a}} \pm 2$ & $17^{\mathrm{a}} \pm 2$ & $11^{\mathrm{b}} \pm 3$ & $16^{\mathrm{a}} \pm 2$ & $10^{\mathrm{b}} \pm 2$ \\
\hline Trichoderma & $13^{\mathrm{a}} \pm 2$ & $10^{\mathrm{a}} \pm 4$ & $12^{\mathrm{a}} \pm 1$ & $14^{\mathrm{a}} \pm 7$ & $12^{\mathrm{a}} \pm 5$ & $8^{b} \pm 5$ & $13^{\mathrm{a}} \pm 5$ & $9^{b} \pm 3$ \\
\hline P. $10-10$ & $9^{a} \pm 5$ & $9^{a} \pm 3$ & $10^{\mathrm{a}} \pm 0$ & $10^{\mathrm{a}} \pm 1$ & $11^{\mathrm{a}} \pm 4$ & $7^{\mathrm{b}} \pm 1$ & $11^{\mathrm{a}} \pm 6$ & $7^{\mathrm{b}} \pm 1$ \\
\hline
\end{tabular}

Table.5 Diameter of inhibition zone of lactic acid bacteria supernatant obtained at the $\mathrm{pH}$ of the end of culture ( $\mathrm{pHec}$ ) supplemented with or without $\alpha$-chymotrypsin

\begin{tabular}{|c|c|c|c|c|c|c|c|c|}
\hline \multicolumn{9}{|c|}{ Diameter of inhibition (mm) } \\
\hline & \multicolumn{2}{|c|}{$\begin{array}{c}\text { Lb. plantarum. } \\
\text { G100 }\end{array}$} & \multicolumn{2}{|c|}{$\begin{array}{c}\text { Lb. rhamnosus } \\
\text { THT }\end{array}$} & \multicolumn{2}{|c|}{ Lb. brevis L62 } & \multicolumn{2}{|c|}{$\begin{array}{c}\text { P. pentosaceus } \\
\text { hela }\end{array}$} \\
\hline & $\begin{array}{c}\text { no } \\
\alpha \text {-chym. }\end{array}$ & $\begin{array}{c}\text { with } \\
\alpha \text {-chym. }\end{array}$ & $\begin{array}{c}\text { no } \\
\alpha \text {-chym. }\end{array}$ & $\begin{array}{c}\text { with } \\
\alpha \text {-chym }\end{array}$ & $\begin{array}{c}\text { no } \\
\alpha \text {-chym. }\end{array}$ & $\begin{array}{c}\text { with } \\
\alpha \text {-chym }\end{array}$ & $\begin{array}{c}\text { no } \\
\alpha \text {-chym }\end{array}$ & $\begin{array}{c}\text { with } \\
\alpha \text {-chym }\end{array}$ \\
\hline R. stolonifer & $14^{\mathrm{a}} \pm 6$ & $8^{\mathrm{b}} \pm 5$ & $12^{\mathrm{a}} \pm 3$ & $8^{\mathrm{a}} \pm 3$ & $15^{\mathrm{a}} \pm 5$ & $13^{\mathrm{a}} \pm 5$ & $13^{\mathrm{a}} \pm 6$ & $10^{\mathrm{a}} \pm 2$ \\
\hline A. niger & $21^{\mathrm{a}} \pm 4$ & $11^{\mathrm{b}} \pm 0$ & $15^{\mathrm{a}} \pm 5$ & $10^{\mathrm{b}} \pm 2$ & $12^{\mathrm{a}} \pm 8$ & $10^{\mathrm{a}} \pm 4$ & $14^{\mathrm{a}} \pm 5$ & $13^{\mathrm{a}} \pm 6$ \\
\hline Trichoder F14 & $13^{\mathrm{a}} \pm 2$ & $6^{\mathrm{b}} \pm 3$ & $12^{\mathrm{a}} \pm 2$ & $14^{\mathrm{a}} \pm 3$ & $11^{\mathrm{a}} \pm 6$ & $11^{\mathrm{a}} \pm 4$ & $13^{\mathrm{a}} \pm 9$ & $12^{\mathrm{a}} \pm 3$ \\
\hline P. $10-10$ & $9^{\mathrm{a}} \pm 5$ & $7^{b} \pm 4$ & $10^{\mathrm{a}} \pm 4$ & $10^{\mathrm{a}} \pm 1$ & $10^{\mathrm{a}} \pm 1$ & $10^{\mathrm{a}} \pm 6$ & $11^{\mathrm{a}} \pm 4$ & $11^{\mathrm{a}} \pm 1$ \\
\hline
\end{tabular}

$$
\alpha \text {-chym : } \alpha \text {-chymotrypsine }
$$

Table.6 Diameter of lactic acid bacteria supernatant obtained at the $\mathrm{pH} 7$ supplemented with or without $\alpha$-chymotrypsin

\begin{tabular}{|c|c|c|c|c|c|c|}
\hline \multicolumn{7}{|c|}{ Diameter of inhibition (mm) } \\
\hline & \multicolumn{2}{|c|}{$\begin{array}{l}\text { Lb. plantarum. } \\
\text { G100 }\end{array}$} & \multicolumn{2}{|c|}{$\begin{array}{c}\text { Lb. Brevis } \\
\mathrm{L62}\end{array}$} & \multicolumn{2}{|c|}{ P.pentosaceus hela } \\
\hline & $\begin{array}{c}\text { no } \\
\alpha \text {-chym. }\end{array}$ & $\begin{array}{c}\text { with } \\
\alpha-\text { chym. }\end{array}$ & $\begin{array}{c}\text { no } \\
\alpha \text {-chym. }\end{array}$ & $\begin{array}{c}\text { with } \\
\alpha \text {-chym. }\end{array}$ & $\begin{array}{c}\text { no } \\
\alpha-\text { chym. }\end{array}$ & $\begin{array}{c}\text { with } \\
\alpha \text {-chym. }\end{array}$ \\
\hline R. stolonifer & $10^{\mathrm{a}} \pm 3$ & $5^{\mathrm{b}} \pm 6$ & $10^{\mathrm{a}} \pm 4$ & $9^{\mathrm{a}} \pm 6$ & $8^{\mathrm{a}} \pm 2$ & $9^{\mathrm{a}} \pm 5$ \\
\hline A. niger & $10^{\mathrm{a}} \pm 5$ & $7^{a} \pm 3$ & $10^{\mathrm{a}} \pm 7$ & $11^{\mathrm{a}} \pm 2$ & $12^{\mathrm{a}} \pm 3$ & $11^{\mathrm{a}} \pm 3$ \\
\hline Trichod. F14 & $9^{\mathrm{a}} \pm 5$ & $3^{\mathrm{b}} \pm 4$ & $8^{\mathrm{a}} \pm 5$ & $10^{\mathrm{a}} \pm 3$ & $9^{\mathrm{a}} \pm 6$ & $5^{\mathrm{b}} \pm 1$ \\
\hline P. 10-10C & $9^{a} \pm 3$ & $4^{b} \pm 2$ & $6^{\mathrm{a}} \pm 3$ & $5^{\mathrm{a}} \pm 4$ & $7^{\mathrm{a}} \pm 4$ & $9^{a} \pm 3$ \\
\hline
\end{tabular}


Table.7 Comparative study of $\alpha$-chymoptripsin effect on diameter inhibition zones at $\mathrm{pH} 7$ and $\mathrm{pH}_{\mathrm{fc}}$

\begin{tabular}{|c|c|c|c|c|c|c|c|c|}
\hline \multicolumn{9}{|c|}{ Diamètre de la zone d'inhibition (mm) } \\
\hline & \multicolumn{2}{|c|}{$\begin{array}{c}\text { Lb. plantarum. } \\
\text { G100 }\end{array}$} & \multicolumn{2}{|c|}{$\begin{array}{c}\text { Lb. rhamnosus } \\
\text { THT }\end{array}$} & \multicolumn{2}{|c|}{ Lb. brevis L62 } & \multicolumn{2}{|c|}{$\begin{array}{c}\text { Pediococcus } \\
\text { pentosaceus Hela }\end{array}$} \\
\hline & $\mathrm{pH} 7$ & $\mathrm{pH}_{\mathrm{fc}}$ & $\mathrm{pH} 7$ & $\mathrm{pH}_{\mathrm{fc}}$ & $\mathrm{pH} 7$ & $\mathrm{pH}_{\mathrm{fc}}$ & $\mathrm{pH} 7$ & $\mathrm{pH}_{\mathrm{fc}}$ \\
\hline R. stolonifer & $5 a \pm 2$ & $8 \mathrm{a} \pm 3$ & $\mathrm{Nd}$ & $8 \pm 2$ & $9 a \pm 3$ & $13 \pm 3$ & $9 \pm 3$ & $10 \pm 6$ \\
\hline A. niger & $7 a \pm 5$ & $11 \mathrm{a} \pm 5$ & $\mathrm{Nd}$ & $10 \pm 1$ & $11 \mathrm{a} \pm 2$ & $10 \pm 0$ & $11 \pm 5$ & $13 \pm 5$ \\
\hline Trichod. F14 & $3 a \pm 0$ & $6 a \pm 0$ & $\mathrm{Nd}$ & $14 \pm 7$ & $10 \pm 4$ & $11 \pm 3$ & $5 \pm 0$ & $12 \pm 3$ \\
\hline$P$. canesc & $4 a \pm 2$ & $7 a \pm 4$ & $\mathrm{Nd}$ & $10 \pm 4$ & $5 \pm 2$ & $10 \pm 5$ & $9 \pm 2$ & $11 \pm 4$ \\
\hline
\end{tabular}

Fig.1 Antifungal activity of lactic acid bacteria on mold strains

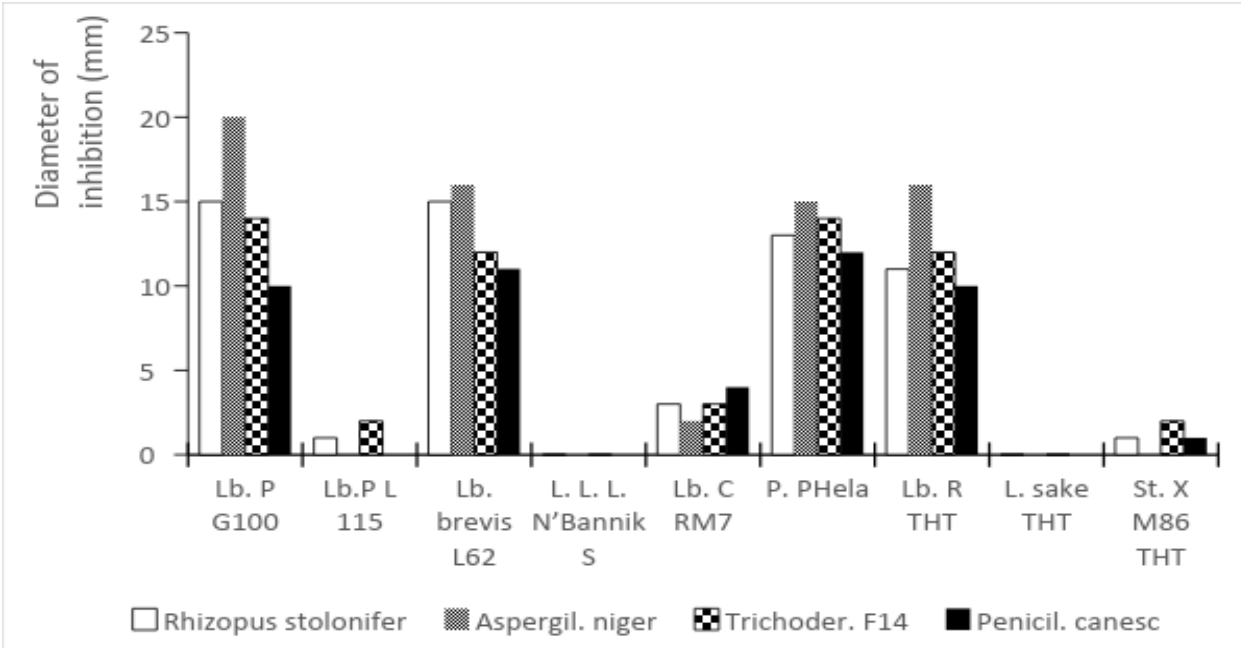

Fig.2 Effect of the acidity of the MRS medium on the growth of different mold strains

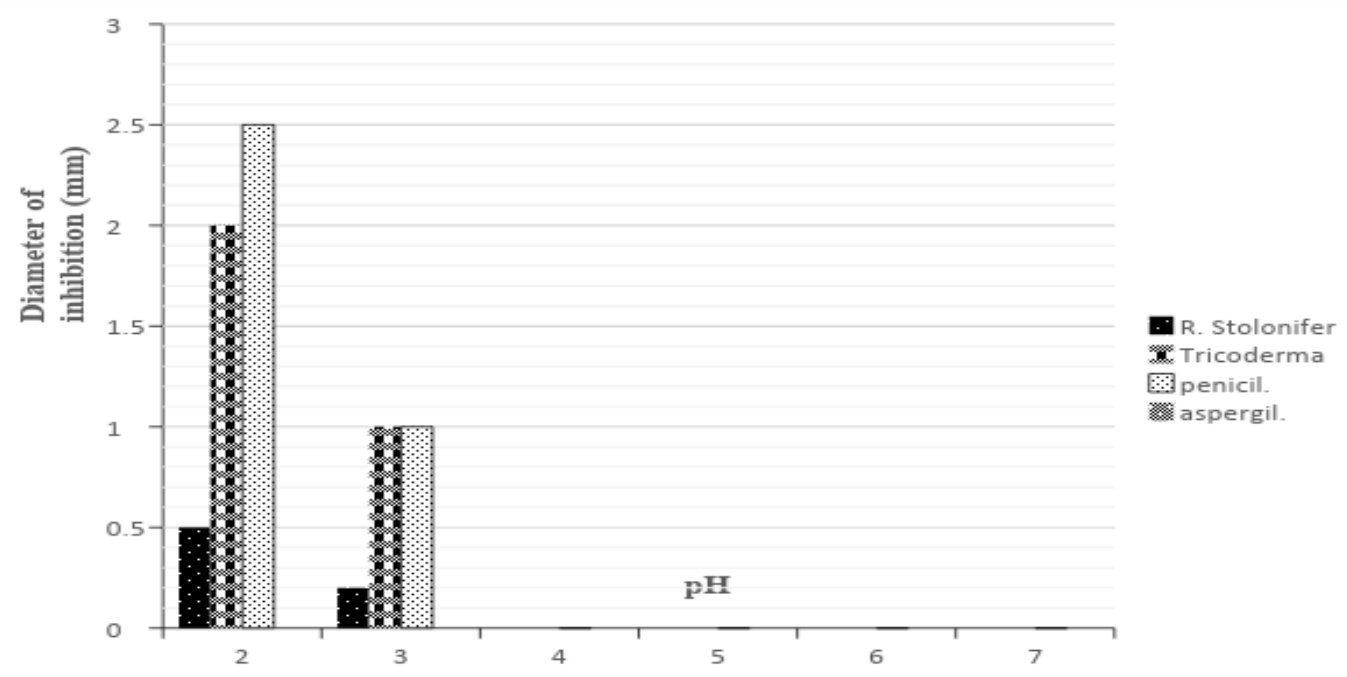


Fig.3 Antifungal activity of lactic acid bacteria at $\mathrm{pH} 7$ on mold strains

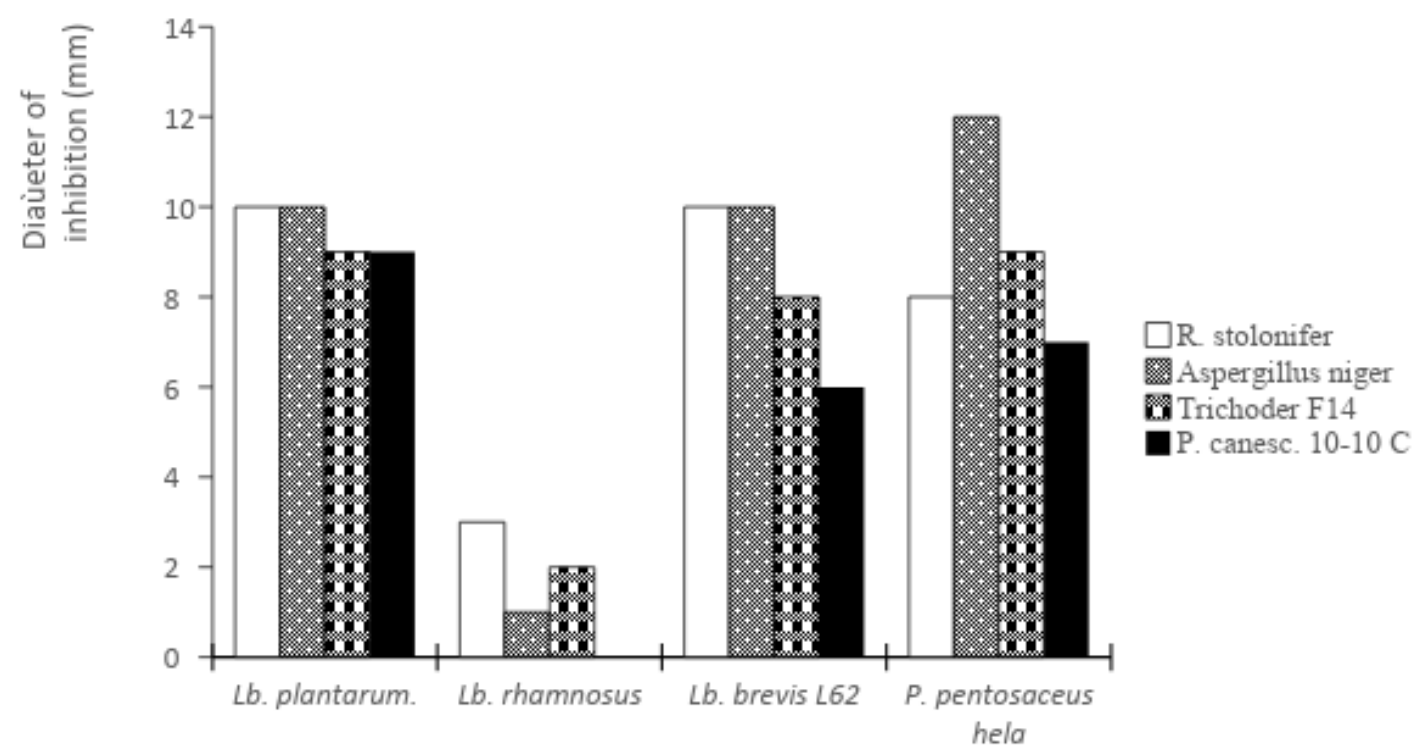

The antifungal activity of L. rhamnosus THT strain depends mostly on the presence of these organic acids and was not affected by the presence of sodium acetate as reported by Stiles et al., (2006). The addition of catalase into the bacterial supernatants obtained at the $\mathrm{pH}$ of the end of culture and at $\mathrm{pH} 7$ showed that not only does hydrogen peroxide act on the fungal species, but its action was amplified by the presence of organic acids. This observation specified the dependence of the antifungal activity of L. brevis L62 and P. pentosaceus Hela strains on the production of hydrogen peroxide, especially in acidic media. Therefore, neutralizing the action of the organic acids would lead to a reduce effect of the hydrogen peroxide. These results were in agreement with that reported by Leveau and Bouix, (1999) who argued that hydrogen peroxide was much more stable when the $\mathrm{pH}$ of the medium was low. Gourama (1997) had also highlighted the importance of the peroxide in the inhibition of Penicillium spores.

Although affected by the adjustment of $\mathrm{pH}$ of the medium to 7, Lactobacillus plantarum G100 still remains insensitive to the action of hydrogen peroxide, but its antagonism effect was reduced after subjecting its supernatant to a protease treatment at this same $\mathrm{pH}$ of 7 . Lactobacillus plantarum G100 activity could be ascribe to the presence of peptide compounds as well as that of organic acids. Moreover, a synergistic effect between these two compounds was observed. Corsetti, et al., (2007) highlighted the efficiency of Lactobacillus plantarum action against strains of Aspergillus ssp. But this activity was related to the production of a mixture of several acids: acetic, caproic, formic, propionic, butyric and n-valeric acid, among which caproic acid had the strongest inhibition effect. In the study conducted by Lavermicocca et al., (2000) only two antifungal compounds produced by $\mathrm{Lb}$ plantarum ITM21B have been purified and characterized as phenyllactic acid and 4hydroxy-phenyllactic acid. Phenyllactic acid had been reported to exhibit a broad spectrum of inhibition against Aspergillus niger and $\mathrm{P}$. roqueforti and therefore able to extend the shelf life of bread (Lavermicocca et al., 2003). The peptide nature of the antifungal compounds produced by lactic acid bacteria in general and $\mathrm{Lb}$ plantarum in particular has 
been documented. Research studies have shown that a loss of the antifungal activity of the lactic acid bacteria was noticeable when subjected to a proteolytic enzymes treatment (Paavola et al., 1999; Roy et al., 1996). The work of Magnusson and Schnürer (2001) demonstrated the ability of a peptide compound produced by L. coryniformis ssp to inhibit Penicillium paneum growth. The inhibitory effect was even higher when the $\mathrm{pH}$ of the medium was between 3 and 4.5. Loss of this activity was remarked when $\mathrm{pH}$ was above 6. Lastly, whatever the nature of the metabolites secreted into the culture medium, their activities remained effective when the $\mathrm{pH}$ was acidic and quite similar to the $\mathrm{pH}$ observed at the end of the culture period.

In conclusion, lactic bacteria displayed an effective inhibitory effect on fungal species such as Penicillium canescens 10-10 C, Aspergillus niger, Trichoderma and $R$. stolonifer. These lactic bacteria could therefore be considered as excellent producers of antifungal metabolites against mold growth. Lactobacillus rhamnosus THT exhibited an antifungal activity through the production of organic acids while that of $\mathrm{L}$. brevis L62 and $P$. pentosaceus hela strains was ascribed to the hydrogen peroxide production. Antifungal metabolite of peptide nature was observed for $L b$ plantarum.

In the light of this study it could be sated that lactic acid bacteria could be used as excellent alternative in the replacement of synthetic molecules used for food preservation.

\section{References}

Corsetti, A., Gobbetti, M., Balestrieri, F., Paoletti, F., Russi, L. \& Rossi, J. 1998. Sourdough lactic acid bacteria effects on bread firmness and staling. J Food Sci 63, 347-351
Corsetti, A., Settanni, L., Valmorri S., Mastrangelo, M., Suzzi, G.2007. Identification of subdominant sourdough lactic acid bacteria and their evolution during laboratory-scale fermentations. Food Microbiology. 24: 592-600

Deirdre P. Lowe, Elke K. Arendt. 2004. The Use and Effects of Lactic Acid Bacteria in Malting and Brewing with Their Relationships to Antifungal Activity, Mycotoxins and Gushing: A Review. J. Inst. Brew. 110(3), 163-180.

Drouault, S., and Corthier, G. 2001. Effets des bactéries lactiques ingérées avec des laits fermentés sur la santé. Vet. Res. 32 101-117 101 @ INRA, EDP Sciences.

Gourama H. 1997. Inhibition of growth and mycotoxin production of Penicillium by Lactobacillus species. Lebensm-Wiss uTechnol 30:279-28

Lavermicocca P, Valerio F, Visconti A. 2003. Antifungal activity of phenyllactic acid against molds isolated from bakery products. Appl Environ Microbiol 69:634-640

Lavermicocca, P., Valerio, F., Evidente, A., Lazzaroni, S., Corsetti, A. and Gobbetti, M. 2000. Purification and characterization of novel antifungal compounds from sourdough Lactobacillus

platarum strain 21B. Applied and Environmental Microbiology66, 40844090.

Leveau J. P. Bouix M. 1993. Microbiologie industrielle. Ed: Techniques et Documentations. Lavoisier Paris. 2-39

Lowe, D., Arendt, K. 2004. The Use and Effects of Lactic Acid Bacteria in Malting and Brewing with Their Relationships to Antifungal Activity, Mycotoxins and Gushing: A Review Journal of the Institue of Brewing. 110(3), pp 163-180. 
Magnusson, J., and J. Schnurer. 2001. Lactobacillus coryniformis subsp. coryniformis strain $\mathrm{Si} 3$ produces a broad-spectrum proteinaceous antifungal compound. Appl. Environ. Microbiol. 67:1-5.

Montville TJ, Matthews KR. 2001. Chapter 2: Principles, which influence microbial growth, survival, and death in foods. In: Doyle MP, Beuchat LR, Montville TJ, editors. Food microbiology: fundamentals and frontiers. Washington (DC): ASM Pr. p 13-32.

Nielsen, P. V., \& de Boer, E. 2000. Food preservatives against fungi. In Introduction fo food- and airborne fungi (Eds.: R. A. Samson, E. S. Hoekstra, J. C. Frisvad and O. Filtenborg) (pp. 357363).

Paavola ML, Laitila A, Mattila-Sandholm T, Haikara A. 1999. New types of antimicrobial compounds produced by Lactobacillus plantarum. J Appl Microbiol 86: 29-35.
Pitt, J. I., Hocking, A. D. 1999. Fungi and food spoilage, 2nd ed. Gaithersburg: Aspen Publishers.

Roy, D., Goulet, J. and LeDuy, A. 1986). Batch fermentation of whey ultrafiltrate by Lactobacillus helveticus for lactic acid production. Appl. Microbiol. Biotechnol., 24, 206-213

Schnürer J., Magnusson J. 2005. Antifungal lactic acid bacteria as biopreservatives. Trends in Food Science \& Technology. 16, 70-78.

Stiles, J., S. Penkar, M. Plockova, J. Chumchalova and L.B. Bullerman, 2002. Antifungal activity of sodium acetate and Lactobacillus rhamnosus. J. Food Prot., 65: 1188-1191.

Stiles, M.E. 1996. Biopreservation by lactic acid bacteria. Antonie Van Leeuwenhoek 70, 331-345.

Ström K. 2005. Fungal Inhibitory Lactic Acid Bacteria. Characterization and Application of Lactobacillus plantarum MiLAB 393. Doctoral thesis. Swedish University of Agricultural Sciences, Uppsala.

\section{How to cite this article:}

Cissé Mohamed, N'guessan Elise Amoin and Assoi Sylvie. 2019. Identification of Antifungal Metabolites of Lactic Acid Bacteria. Int.J.Curr.Microbiol.App.Sci. 8(01): 109-120. doi: https://doi.org/10.20546/ijcmas.2019.801.014 